\title{
Der seltsame Schneemann
}

\section{E. Taverna}

Von einem standhaften Schneemann, der nicht einfach wegschmilzt, sondern mit einem Zirkus auf die Reise geht. Eine vergnügliche Geschichte, die so endet, wie sie beginnt. Ein sehr schön illustriertes Märchen von einem Kerl mit blauer Mütze und blauem Schal, mit der klassischen Rübennase und schwarzen Kohleaugen.

Ein Bilderbuch für Kinder zu Hause und im Wartezimmer und zum Schmunzeln für Junggebliebene.

\section{Autorin:}

Dr. med. Catherine Wehren, Missionsstrasse 34, 4055 Basel. Ärztin mit eigener Praxis, erfindet Geschichten und zeichnet gerne.

\section{Illustratorin:}

Sabine Wiemers, zeichnet unter anderem zu Liedern und Geschichten für "Die Sendung mit der Maus» (WDR-Kinderfernsehen).

Der seltsame Schneemann. Basel: Friedrich Reinhardt Verlag; 2000.

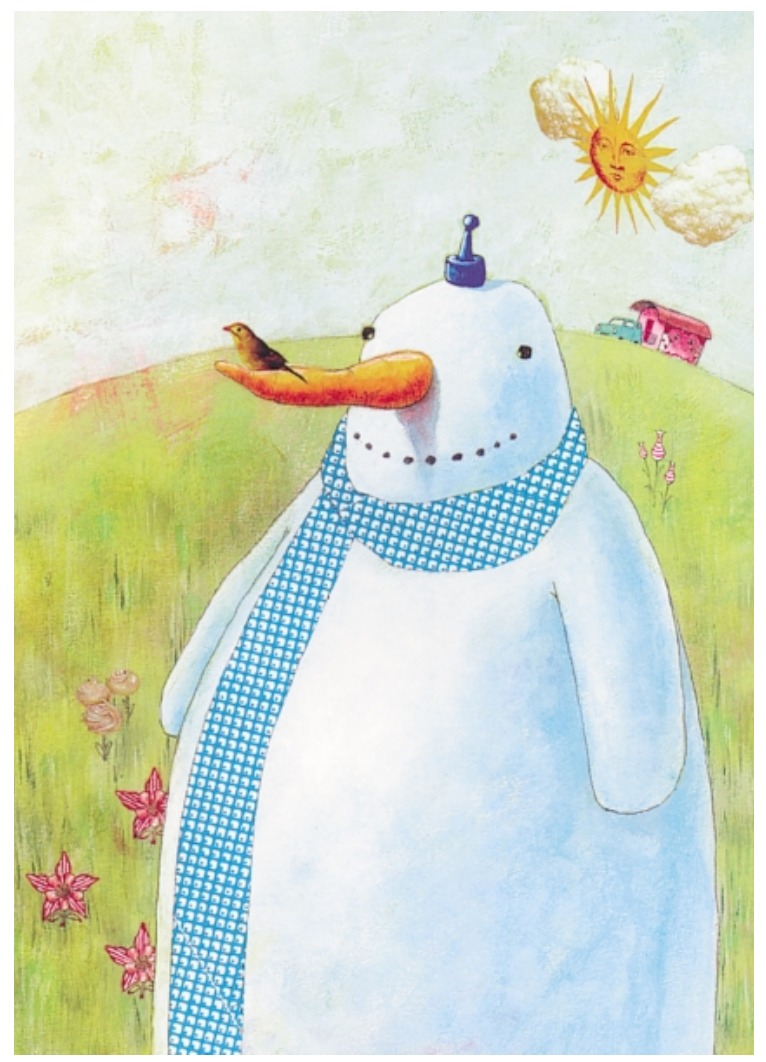

